\title{
JC polyomavirus infection in candidates for kidney transplantation living in the Brazilian Amazon Region
}

\author{
Fernando Assis Ferreira Melo ${ }^{1}$, Ana Caroline Fonseca Bezerra ${ }^{2}$, \\ Bárbara Brasil Santana ${ }^{3}$, Marluísa Oliveira Guimarães Ishak ${ }^{3}$, Ricardo Ishak ${ }^{3}$, \\ Izaura Maria Vieira Cayres-Vallinoto ${ }^{3}$, Antonio Carlos Rosário Vallinoto ${ }^{1 /+}$ \\ ${ }^{1}$ Hospital das Clínicas do Acre, Rio Branco, AC, Brasil Faculdade de Medicina, Universidade Federal do Acre, Rio Branco, AC, Brasil \\ ${ }^{3}$ Laboratório de Virologia, Instituto de Ciências Biológicas, Universidade Federal do Pará, Belém, PA, Brasil
}

This study evaluated the relative occurrences of BK virus (BKV) and JC virus (JCV) infections in patients with chronic kidney disease (CKD). Urine samples were analysed from CKD patients and from 99 patients without CKD as a control. A total of 100 urine samples were analysed from the experimental (CKD patients) group and 99 from the control group. Following DNA extraction, polymerase chain reaction (PCR) was used to amplify a 173 bp region of the gene encoding the T antigen of the BKV and JCV. JCV and BKV infections were differentiated based on the enzymatic digestion of the amplified products using $\mathrm{BamHI}$ endonuclease. The results indicated that none of the patients in either group was infected with the BKV, whereas $11.1 \%$ (11/99) of the control group subjects and 4\% (4/100) of the kidney patients were infected with the JCV. High levels of urea in the excreted urine, low urinary cellularity, reduced bladder washout and a delay in analysing the samples may have contributed to the low prevalence of infection. The results indicate that there is a need to increase the sensitivity of assays used to detect viruses in patients with $C D K$, especially given that polyomavirus infections, especially BKV, can lead to a loss of kidney function following transplantation.

Key words: polyomavirus infection - JCV - BKV - chronic renal disease - kidney transplant

Two human polyomaviruses (BK and JC) were discovered more than 40 years ago (Gardner et al. 1971, Padgett et al. 1971). The JC virus (JCV) is the causative agent of progressive multifocal leukoencephalopathy (Padgett et al. 1971), which primarily affects immunosuppressed acquired immune deficiency syndrome (AIDS) patients. The BK virus (BKV) is associated with disorders such as haemorrhagic cystitis, urethral stenosis and other urinary tract diseases most commonly found in patients awaiting transplants or undergoing immunosuppressive therapy (Drachenberg et al. 2007).

The two viruses are widespread in the human population, with prevalence of $63 \%$ for BKV and $80 \%$ for JCV (Padgett et al. 1971, White \& Khalili 2004). Primary infection with JCV usually occurs during childhood and is asymptomatic (Padgett \& Walker 1973). At the site of entry, which is normally the respiratory tract, these viruses replicate and traffic to the tissues of the kidneys (Heritage et al. 1981, McCance 1983) and the central nervous system, where they sustain a long-term infection (Elsner \& Dörries 1992, Quinlivan et al. 1992). A recurrence of the infection may be induced by significant immunosuppression, as in the case of kidney (Hogan et al. 1980, Kahan et al. 1980, Gardner et al. 1984) and bone

Financial support: CNPq (474907/2006-6), PROPESP/FADESP/UFPA + Corresponding author: vallinoto@ufpa.br

Received 14 February 2012

Accepted 9 October 2012 marrow transplants (O'Reilly et al. 1981, Arthur et al. 1988 ) and other factors such as immunodeficiency diseases, diabetes, other chronic diseases, immunosuppressive chemotherapy, pregnancy (Coleman et al. 1980) and old age (Tajima et al. 1990).

Primary infection with BKV possibly occurs through the respiratory tract during early childhood, with the virus remaining dormant in the urinary tract and other organs (Goudsmit et al. 1982). This primary infection is usually asymptomatic, but it may induce a fever and nonspecific respiratory symptoms (Reploeg et al. 2001). This virus can also be transmitted through organ transplantation (Fioriti et al. 2005).

Reactivation of the BKV may occur spontaneously in immunocompetent subjects and is relatively frequent in individuals with impaired cellular immunity, such as pregnant women, cancer patients receiving chemotherapy, AIDS patients and transplant recipients. In these patients, the virus can cause haemorrhagic cystitis, nephritis, urethral stenosis and a loss of function of the transplanted kidney (Coleman et al. 1978, Gardner et al. 1984, Chan et al. 1994, Weiskittel 2002).

The presence of BKV has been associated with rejection of the transplanted kidney, whereas JCV has been associated with nonspecific symptoms in the transplanted kidney, lungs and pancreas (Weiskittel 2002).

Reactivation of BKV is now responsible for $10-60 \%$ of the cases of the loss of function of the grafted organ in kidney transplants (Hurault de Ligny et al. 2003). This polyomavirus causes tubulointerstitial nephritis in the kidney tissue, which is known as polyomavirus-associated nephropathy (Hirsch et al. 2006). 
The detection of polyomaviruses in kidney transplant candidates (patients with chronic renal disease) should be a standard component of pre-transplant research, especially given the potential role these viruses play in graft rejection (Pires et al. 2011). The differential diagnosis of these viruses is also essential, given that they are histologically similar, but require distinct courses of treatment (Elli et al. 2002).

This study aimed to evaluate the relative prevalence of JCV and BKV infections in kidney transplant candidates with chronic renal disease from the Brazilian state of Acre (AC) and the possible association between clinical or laboratory factors of disease and socio-demographic variables.

\section{SUBJECTS, MATERIALS AND METHODS}

Sample groups - Urine samples were collected from 199 volunteer subjects between April-July 2008. All subjects were over 18 years old and resided in Rio Branco, the capital of AC.

The experimental group consisted of 100 patients diagnosed with chronic kidney disease (CKD). All subjects were undergoing haemodialysis treatment at the Clinical Hospital of Acre (HCA).

The control group consisted of 99 patients from the HCA without any symptoms of acute or CKD or any other urinary tract disorder. All samples were sent to the Virus Laboratory of the Biological Sciences Institute of the Federal University of Pará (UFPA).

Ethics - All subjects were contacted prior to the study and provided with information on its aims. Those subjects who agreed to participate in the study by providing a urine sample were required to sign an informed consent form. The project was submitted to the Research Ethical Commission of the UFPA Medical Sciences Institute and was authorised under protocol 090/06. The study followed the guidelines and regulatory standards of the Brazilian National Health Council (Resolution 196/96) for research involving human subjects.

Sample collection - Urine samples (mean volume $15.2 \pm 5.3 \mathrm{~mL}$, range $5-50 \mathrm{~mL}$ ) were collected in sterile flasks. At the UFPA Virus Laboratory, the samples were centrifuged at 3,640 $\mathrm{g}$ for $15 \mathrm{~min}$ until the urine residue was completely separated. The sediment was then washed three times with a sterile saline solution $(0.9 \%)$ and the cell pellet was frozen at $-20^{\circ} \mathrm{C}$ until the DNA could be extracted, as described by Pires et al. (2011).

DNA extraction - DNA was extracted from the cell pellets following the protocol for viral nucleic acid extraction using a Link Pure Viral RNA/DNA kit (Invitrogen, CA, USA).

Molecular analysis - The presence of JCV and/or BKV was evaluated by amplifying a $173 \mathrm{bp}$ fragment of the gene encoding the $\mathrm{T}$ antigen of both viruses, which was amplified by polymerase chain reaction (PCR) as described by Pires et al. (2011). DNA samples from previously confirmed JCV and $\mathrm{BKV}$ infected subjects, stored at $-20^{\circ} \mathrm{C}$, were used as positive controls in all PCR assays.

JCV or BKV infections were confirmed by enzymatic digestion of the amplified product using the restriction endonuclease BamHI (2 U/ $\mu \mathrm{g}$ of DNA) (Invitrogen, CA, USA), which cleaves the amplified product from JCV into $120 \mathrm{bp}$ and $53 \mathrm{bp}$ fragments, but does not cleave the amplified product from BKV. The products of this digestion were visualised using 3\% agarose gel electrophoresis as previously described (Pires et al. 2011).

To test the quality of the extracted DNA and for the presence of polymerase inhibitors, all samples were used to amplify a $349 \mathrm{bp}$ segment of the human gene Mbl2 as an internal control following a previously described protocol (Vallinoto et al. 2009).

Statistical analysis - Descriptive statistics, including absolute (n) and relative (\%) frequencies or mean, standard deviation, median and range, were calculated separately for the two study groups. The significances of between-group differences in discrete socio-demographic variables (sex ratio, education level and place of birth) and the possible association between JVC infection and clinical variables were assessed using the chi-square or likelihood ratio tests, where applicable. For continuous variables, the Kolmogorov-Smirnov test was first applied to determine the normal distribution of the data and a $t$ test was then used to compare mean ages and urea and creatinine levels between groups. A paired $t$ test was used to compare pre and post-dialysis urea levels in the kidney patients. A significance level of $0.05(\alpha=5 \%)$ was adopted and $p$ values lower than this were considered significant. All statistical analyses were run on SPSS software for Windows, version 15.0 (Chicago, USA).

\section{RESULTS}

Social and demographic variables - There were no statistically significant differences between the experimental and control groups (Table I) for the sex ratio $(\mathrm{p}=$ $0.523)$, mean age $(p=0.648)$, age distribution $(p=0.634)$, education levels $(p=0.241)$ or birthplace $(p=0.117)$.

Clinical and laboratory analyses - The creatinine and urea serum levels of the subjects were recorded (Table II); in the case of urea, pre and post-dialysis levels were also recorded for the kidney patients (Table III). Mean urea serum levels were significantly higher $(\mathrm{p}<0.001)$ in the experimental group (kidney patients) compared to the control group, as were the mean creatinine levels ( $\mathrm{p}$ $<0.001)$. In the kidney patients, as expected, urea concentrations declined significantly following dialysis in all patients $(\mathrm{p}<0.001)$, with a mean reduction of $86.4 \pm$ $39.1 \mathrm{mg} / \mathrm{dL}$, range $=17-191 \mathrm{mg} / \mathrm{dL}$ (Table III). Overall, $77(77 \%)$ of the patients had post-dialysis levels of urea above $35 \mathrm{mg} / \mathrm{dL}$ (the upper limit of the normal range), whereas the values for the remaining 23 patients (23\%) were within normal limits.

Prevalence of polyomaviruses - The JCV was identified in $11.1 \%$ (11/99) of the subjects in the control group and $4 \%(4 / 100)$ of those in the CKD patient group (Table IV). Five DNA samples from CKD patients were unable to amplify the $349 \mathrm{bp}$ fragment of the human gene Mbl2. The BKV was not identified in any of the urine samples. There were no statistically significant differences between JCV infection and sex $(\mathrm{p}=0.773)$, age $(\mathrm{p}=0.567)$, race $(p=0.078)$ or place of birth, $p=0.516$ (Table IV). 
TABLE I

Socio-demographic characteristics of the two study groups

\begin{tabular}{|c|c|c|c|c|}
\hline \multirow[b]{2}{*}{ Variable } & \multicolumn{3}{|c|}{$\begin{array}{l}\text { Subjects } \\
\mathrm{n}(\%)\end{array}$} & \multirow[b]{2}{*}{$\mathrm{p}^{a}$} \\
\hline & $\begin{array}{l}\text { CKD patients } \\
\quad(\mathrm{n}=100)\end{array}$ & $\begin{array}{l}\text { Control group } \\
\quad(\mathrm{n}=99)\end{array}$ & $\begin{array}{c}\text { Total sample } \\
\quad(\mathrm{n}=199)\end{array}$ & \\
\hline \multicolumn{5}{|l|}{ Education level } \\
\hline Illiterate & $19(19)$ & $26(26.3)$ & $45(22.6)$ & 0.241 \\
\hline Literate & $33(33)$ & $28(28.3)$ & $61(30.7)$ & \\
\hline Elementary school & $34(34)$ & $23(23.2)$ & $57(28.6)$ & \\
\hline High school & $9(9)$ & $13(13.1)$ & $22(11.1)$ & \\
\hline University & $5(5)$ & $9(9.1)$ & $14(7)$ & \\
\hline \multicolumn{5}{|l|}{ Place of birth } \\
\hline Acre & $77(77)$ & $63(63.6)$ & $140(70.4)$ & 0.117 \\
\hline Other Brazilian state & $21(21)$ & $33(33.3)$ & $54(27.1)$ & \\
\hline Other country & $2(2)$ & $3(3)$ & $5(2.5)$ & \\
\hline
\end{tabular}

$a$ : $\mathrm{p}$ values for the comparison between experimental and control groups; CKD: chronic kidney disease.

\section{DISCUSSION}

The polyomavirus infection rates recorded in this study were considerably lower than those reported in other Brazilian populations (Cayres-Vallinoto 2008, Pires et al. 2011). Cayres-Vallinoto (2008) reported a JCV infection rate of $33 \%$ in the city of Belém, state of Pará, whereas Pires et al. (2011) reported prevalence of 3.9\% in patients diagnosed with CKD and $22.4 \%$ in asymptomatic subjects. In Europe, Rodrigues et al. (2007) analysed the excretion of polyomaviruses in the urine of Portuguese subjects and reported a prevalence of $25.7 \%$. Additionally, polyomavirus infection rates may vary considerably between different sectors of the country's population. For example, Suzuki et al. (2002) reported an infection rate of $18 \%$ for Americans of European descent, but a rate of 53\% for those of Japanese descent. The low rates of polyomavirus infection reported here may represent an epidemiological feature of the virus in $\mathrm{AC}$, which may be related to the population density and environmental conditions, which are of paramount importance for JCV and BKV transmission (Bofill-Mas \& Girones 2001, Bofill-Mas et al. 2003). Thus, it is crucial to investigate the infection rates in different regions of Brazil and in distinct ethnic groups to establish the real prevalence of these viruses.

In this study, JCV infection was rare and BKV infection was absent from the samples analysed, which may suggest possible problems with the PCR analysis resulting from either inadequate sample collection and processing or other factors arising during analysis. In particular, urine samples destined for PCR should not be stored for long periods prior to processing because there is a tendency for the sample to alkalinise, which may result in a false negative result (Khan et al. 1991). In this study, the time between the sample collection and the urine sample analyses (mean of 2 days) may have led to a change in the $\mathrm{pH}$ of the material, which could have inhibited the PCR, resulting in reduced viral detection.
TABLE II

Serum levels of urea and creatinine recorded in the samples collected from the two study groups

\begin{tabular}{lccc}
\hline & \multicolumn{2}{c}{$\begin{array}{c}\text { Concentration } \\
(\mathrm{mg} / \mathrm{dL})\end{array}$} \\
\cline { 2 - 3 } & \multicolumn{2}{c}{$\begin{array}{c}\text { CKD patients } \\
(\mathrm{n}=100)\end{array} \quad \begin{array}{c}\text { Control group } \\
(\mathrm{n}=99)\end{array}$} \\
Substance & $\mathrm{p}$ \\
\hline Urea & $140.9(45.9)$ & $24.2(6.4)$ & $<0.001$ \\
$\quad$ Mean (SD) & 134.0 & 23.0 & \\
Median & $43-236$ & $12-35$ & \\
Minimum-maximum & & & \\
Creatinine & $11.04(3.81)$ & $0.96(0.24)$ & $<0.001$ \\
$\quad$ Mean (SD) & 11.35 & 0.90 & \\
Median & $2.6-19.0$ & $0.4-1.5$ & \\
Minimum-maximum & &
\end{tabular}

CKD: chronic kidney disease; SD: standard deviation.

Two additional factors could also have been important in the case of the kidney disease patients: the high concentrations of urea in the pre-dialysis samples and the mucoid secretions produced by the urinary tract epithelium, which are among the substances known to inhibit PCR (Al-Soud \& Râdström 1998). Thus, the differences in JCV prevalence between the study groups may have been at least partly due to the significant difference in urea levels. Additionally, Behzadbehbahani et al. (1997) observed that high levels of urea inhibited the amplification of segments of the BKV genome.

Similarly, subjects with bladder dysfunction due to low urine volume and low frequency of urination, which is typical in haemodialysis patients, tend to accumulate 
TABLE III

Serum urea levels in the pre and post-dialysis samples obtained from the chronic kidney disease patients

\begin{tabular}{lcccc}
\hline & \multicolumn{2}{c}{$\begin{array}{c}\text { Concentration of urea } \\
(\mathrm{mg} / \mathrm{dL})\end{array}$} & & \\
& \multicolumn{2}{c}{$\begin{array}{c}\text { Reduction } \\
\text { (pre-post) }\end{array}$} & $\mathrm{p}$ \\
\cline { 2 - 3 } Parameter $(\mathrm{n}=100)$ & Pre-dialysis & Post-dialysis & & $<6.4(39.1)$ \\
\hline Mean (SD) & $140.9(45.9)$ & $54.6(22.1)$ & 78.5 & \\
Median & 134.0 & 54.50 & $17-191$ & \\
Minimum-maximum & $43-236$ & $13-109$ & & \\
\hline
\end{tabular}

SD: standard deviation.

large amounts of mucoid secretions in the bladder (Han et al. 2002). Once again, this may have been a factor that contributed to the PCR inhibition in this study.

Other factors (polymerase inhibitors) that may have interfered with the results, especially those of the experimental group, include changes in $\mathrm{pH}$, chelation of magnesium ions and the abnormal quantities of haemoglobin and glycoproteins typically found in the urine of patients with CKD (Mahbudani \& Bej 1974, Greenfield \& White 1993, Bej \& Mahbubani 1994, Panaccio \& Lew 1994). Patients with chronic renal failure requiring haemodialysis (endstage renal function-creatinine clearance $<20-15 \mathrm{~mL} /$ $\mathrm{min} / \mathrm{m}^{2}$ ) also develop significant morphological changes in the renal parenchyma characterised histologically by glomerular hypertrophy, formation of intraglomerular thrombus, excessive proliferation of glomerular cells and mesangial matrix, glomerular deposition of lipids, stretching of the mesangial and endothelial cells, injury to the podocyte and subendothelial deposition of protein. These histological changes are characterised morphologically by the atrophy of the renal parenchyma with decreased volume and organ function (Romão 2004). Thus, the low cellularity of the urine (caused by renal atrophy) may have also contributed to reduced polyomavirus detection in the experimental group. These hypotheses involving polymerase inhibitors are being raised here because we were unable to amplify the $349 \mathrm{bp}$ fragment of the human gene Mbl2 from a few of the patient samples.

As the polyomavirus replicates in the renal parenchyma, it seems likely that fewer viruses will be shed into the urine of individuals with reduced renal parenchyma activity. Once again, this may have contributed to the reduced prevalence of polyomavirus in the kidney patients reported here.

Finally, the results obtained here are of paramount importance because they highlight the clear need to improve the sensitivity of the methods used to detect polyomavirus in the urine of patients with chronic renal failure (kidney transplant candidates), especially given the potentially harmful effects of these viruses, which may cause a loss of function of the transplanted organ. As we have proposed previously (Pires et al. 2011), the use of a real-time PCR assay could be an alternative method for improving the sensitivity of detecting viral DNA even when there are low viral titres.
TABLE IV

Prevalence of JV virus

in the study population by demographic variable

\begin{tabular}{lccc}
\hline & \multicolumn{2}{c}{$\begin{array}{c}\text { Subjects } \\
\mathrm{n}(\%)\end{array}$} & \\
\cline { 2 - 3 } Variable & Negative & Positive & $\mathrm{p}$ \\
\hline Sex (n) & & & \\
Male (99) & $91(91.9)$ & $8(8.1)$ & 0.773 \\
Female (100) & $93(93)$ & $7(7)$ & \\
Age class [years (n) & & & \\
$<$ 20 (4) & $4(100)$ & $0(0)$ & 0.567 \\
20-29 (8) & $7(87.5)$ & $1(12.5)$ & \\
30-39 (24) & $21(87.5)$ & $3(12.5)$ & \\
40-49 (41) & $37(90.2)$ & $4(9.8)$ & \\
$50-59$ (58) & $53(91.4)$ & $5(8.6)$ & \\
60-69 (55) & $53(96.4)$ & $2(3.6)$ & \\
$70-79$ (9) & $9(100)$ & $0(0)$ & \\
Skin colour (n) & & & \\
White (60) & $54(90)$ & $6(10)$ & 0.078 \\
Black (39) & $35(89.7)$ & $4(10.3)$ & \\
Yellow (30) & $26(86.7)$ & $4(13.3)$ & \\
Indian brown (24) & $24(100)$ & $0(0)$ & \\
Negroid (46) & $45(97.8)$ & $1(2.2)$ & \\
Place of birth (n) & & & \\
Acre (140) & $128(91.4)$ & $12(8.6)$ & 0.516 \\
Other Brazilian state (54) & $51(94.4)$ & $3(5.6)$ & \\
Other country (5) & $5(100)$ & $0(0)$ & \\
\hline
\end{tabular}

\section{ACKNOWLEDGEMENTS}

To the subjects, for participating in the present study.

\section{REFERENCES}

Al-Soud WA, Râdström P 1998. Capacity of nine thermostable DNA polymerases to mediate amplification in the presence of PCRinhibiting samples. Appl Environ Microbiol 64: 3748-3753.

Arthur CK, Apperley JF, Guo AP, Rassool F, Gao LM, Goldman JM 1988. Cytogenetic events after bone marrow transplantation for chronic myeloid leukemia in chronic phase. Blood 71 : 1179-1186. 
Behzadbehbahani A, Klapper PE, Vallely PJ, Cleator GM 1997. Detection of BK virus in urine by polymerase chain reaction: a comparison of DNA extraction methods. J Virol Methods 67: 161-166.

Bej AK, Mahbubani MH 1994. Thermostable DNA polymerase for in vitro DNA amplification. In H Griffin, A Griffin, PCR technology: current innovations, CRC Press, London, p. 219-237.

Bofill-Mas S, Clemente-Casares P, Major EO, Curfman B, Girones R 2003. Analysis of the excreted JC virus strain and their potential oral transmission. J Neurovirol 9: 498-507.

Bofill-Mas S, Girones R 2001. Excretion and transmission of JCV in human populations. J Neurovirol 7: 345-349.

Cayres-Vallinoto IMV 2008. Molecular epidemiology of human polyomavirus JC in populations of the Brazilian Amazon: a biological marker of human migration, Vol. 1, PhD Thesis, Universidade Federal do Pará, Belém, 134 pp.

Chan PK, Ip KW, Shiu SY, Chiu EK, Wong MP, Yuen KY 1994. Association between polyomaviruria and microscopic hematuria in bone marrow transplant recipients. J Infect 29: 139-146.

Coleman DV, Mackenzie EF, Gardner SD, Poulding JM, Amer B, Russell WJ 1978. Human polyomavirus (BK) infection and ureteric stenosis in renal allograft recipients. J Clin Pathol 31: 338-347.

Coleman DV, Wolfendale MR, Daniel RA, Dhanjal NK, Gardner SD, Gibson PE, Field AM 1980. A prospective study of human polyomavirus infection in pregnancy. $J$ Infect Dis 142: 1-8.

Drachenberg CB, Hirsch HH, Papadimitriou JC, Gosert R, Wali RK, Munivenkatappa R, Nogueira J, Cangro CB, Haririan A, Mendley S, Ramos E 2007. Polyomavirus BK versus JC replication and nephropathy in renal transplant recipients: a prospective evaluation. Transplantation 84: 323-330.

Elli A, Banfi G, Fogazzi GB, Tarantino A, Ponticelli C 2002. BK polyomavirus interstitial nephritis in a renal transplant patient with no previous acute rejection episodes. J Nephrol 15: 313-316.

Elsner C, Dörries K 1992. Evidence of human polyomavirus BK and JC infection in normal brain tissue. Virology 191: 72-80.

Fioriti D, Videtta M, Mischitelli M, Degener AM, Russo G, Giordano A, Pietropaolo V 2005. The human polyomavirus BK: potential role in cancer. $J$ Cell Physiol 204: 402-406.

Gardner SD, Field AM, Coleman DV, Hulme B 1971. New human papovavirus (BK) isolated from urine after renal transplantation. Lancet 1: 1253-1257.

Gardner SD, Mackenzie EF, Smith C, Porter AA 1984. Prospective study of the human polyomaviruses BK and JC and cytomegalovirus in renal transplant recipients. J Clin Pathol 37: 578-586.

Goudsmit J, Wertheim-van Dillen P, van Strien A, van der Noordaa J 1982. The role of BK virus in acute respiratory tract disease and the presence of BKV DNA in tonsils. J Med Virol 10: 91-99.

Greenfield L, White TJ 1993. Sample preparation methods. In D Persing, T Smith, F Tenover, TJ White, Diagnostic molecular microbiology: principles and applications, ASM Press, Washington DC, p. 122-137.

Han C, Dai F, Zhou G 2002. Urodynamics of neurogenic lower urinary tract disfunction caused by spinal cord injury. Zhonghua Wai Ke Za Zhi 40: 441-444.

Heritage J, Chesters PM, McCance DJ 1981. The persistence of papovavirus BK DNA sequences in normal human renal tissue. J Med Virol 8: 143-150.

Hirsch HH, Drachenberg CB, Steiger J, Ramos E 2006. Polyomavirusassociated nephropathy in renal transplantation: critical issues of screening and management. Adv Exp Med Biol 577: 160-173.

Hogan TF, Borden EC, McBain JA, Padgett BL, Walker DL 1980. Human polyomavirus infections with JC virus and BK virus in renal transplant patients. Ann Intern Med 92: 373-378.
Hurault de Ligny B, Francois A, Lobbedez T, Comoz F, Etienne L, El Haggan W, Pujo M, Ryckelunck JP 2003. Clinical aspects of human polyomaviruses in renal transplantation. Presse Med 32: 659-666.

Kahan A, Coleman D, Koss L 1980. Activation of human polyomavirus infection detection by cytologic technics. Am J Clin Pathol 74: 326-332.

Khan G, Kangro HO, Coates PJ, Heath RB 1991. Inhibitory effects of urine on the polymerase chain reaction for cytomegalovirus DNA. J Clin Pathol 44: 360-365.

Mahbudani MH, Bej AK 1974. Applications of polymerase chain reaction methodology in clinical diagnostics. In H Griffin, A Griffin, PCR technology: current innovations, CRC Press, London, p. $307-326$

McCance D 1983. Persistence of animal and human papovaviruses in renal nervous tissues. In JL Sever, DL Madden, Polyomaviruses and human neurological disease, Alan R Liss, New York, p. 343-357.

O'Reilly RJ, Lee FK, Grossbard E, Kapoor N, Kirkpatrick D, Dinsmore R, Stutzer C, Shah KV, Nahmias AJ 1981. Papovavirus excretion following marrow transplantation: incidence and association with hepatic dysfunction. Transplant Proc 13: 262-266.

Padgett BL, Walker DL 1973. Prevalence of antibodies in human sera against JC virus, an isolate from a case of progressive multifocal leukoencephalopathy. J Infect Dis 127: 467-470.

Padgett BL, Walker DL, ZuRhein GM, Eckroade RJ, Dessel BH 1971. Cultivation of papova-like virus from human brain with progressive mutifocal leucoencephalopathy. Lancet 1: 1257-1260.

Panaccio M, Lew AM 1994. Direct PCR from whole blood using formamide and low temperatures. In H Griffin, A Griffin, PCR technology: current innovations, CRC Press, London, p. 151-157.

Pires EP, Bernardino-Vallinoto CV, Alves DM, Migone SR, Machado LF, Ishak MO, Ishak R, Cayres-Vallinoto IM, Vallinoto AC 2011. Prevalence of infection by JC and BK polyomaviruses in kidney transplant recipients and patients with chronic renal disease. Transpl Infect Dis 13: 633-637.

Quinlivan EB, Norris M, Bouldin TW, Suzuki K, Meeker R, Smith M, Hall C, Kenney S 1992. Subclinical central nervous system infection with JC virus in patients with AIDS. J Infect Dis 166: 80-85.

Reploeg MD, Storch GA, Clifford DB 2001. BK virus: a clinical review. Clin Infect Dis 33: 191-202.

Rodrigues C, Pinto D, Medeiros R 2007. Molecular epidemiology characterization of the urinary excretion of polyomavirus in healthy individuals from Portugal a southern European population. J Med Virol 79: 1194-1198.

Romão Jr JE 2004. Doença renal crônica: definição, epidemiologia e classificação. J Bras Neurol 26: 1-3.

Suzuki M, Zheng HY, Takasaka T, Sugimoto C, Kitamura T, Beutler $\mathrm{E}$, Yogo Y 2002. Asian genotypes of JC virus in Japanese-Americans suggests familial transmission. J Virol 76: 10074-10078.

Tajima M, Takeda F, Mori M, Shimada H 1990. Prevalence of the antibody against human polyomaviruses (JCV and BKV) in aged persons. Kansenshogaku Zasshi 64: 1507-1513.

Vallinoto ACR, Pinheiro da Silva RF, Hermes RH, Amaral ISA, Miranda ECB, Barbosa MSB, Moia LJP, Conde SRS, Soares MCP, Lemos JAR, Machado LFA, Ishak MOG, Ishak R 2009. Mannose-binding lectin gene polymorphisms are not associated with the susceptibility to HCV infection in the Brazilian Amazon region. Hum Immunol 70: 754-756.

Weiskittel PD 2002. Polyoma virus in renal transplant recipients. Nephrol Nurs J 29: 247-250.

White MK, Khalili K 2004. Polyomaviruses and human cancer: molecular mechanisms underlying patterns of tumorigenesis. Virology 324: 1-16. 